1 Investigating the origin of the Belgian second SARS-CoV-2 wave by using

2 (pre)admission screening samples.

3 Naesens Reinout ${ }^{1,2}$, Heireman Laura ${ }^{1}$, Vandamme Sarah $^{3}$, Willems Philippe ${ }^{4,5}$, Van Herendael

4 Bruno ${ }^{4,5}$, Verstrepen Walter ${ }^{1}$, De Schouwer Pieter ${ }^{1}$, Bruynseels Peggy ${ }^{1,2}$

\title{
5 Affiliations:
}

6 1. Department of Medical Microbiology, ZiekenhuisNetwerk Antwerpen, B-2020

$7 \quad$ Antwerp, Belgium

8 2. Department of Infection Prevention and Control, ZiekenhuisNetwerk Antwerpen, B-

92020 Antwerp, Belgium

10 3. Department of Medical Microbiology, University Hospital Antwerp, B-2650 Edegem,

$11 \quad$ Belgium

4. Department of Medical Microbiology, GasthuisZusters Antwerpen, B-2060 Antwerp, Belgium Antwerp, Belgium

17 Corresponding Author: Reinout Naesens Corresponding Author Email: 
medRxiv preprint doi: https://doi.org/10.1101/2020.12.09.20246462; this version posted December 24, 2020. The copyright holder for this preprint (which was not certified by peer review) is the author/funder, who has granted medRxiv a license to display the preprint in perpetuity.

It is made available under a CC-BY-NC-ND 4.0 International license.

\section{Abstract}

20 The goal of this study was to estimate rates of SARS-CoV-2 carriership and viral loads in the

21 general Antwerp population and to compare the estimated prevalences and incidences with

22 governmental data (numbers of detected positive cases, stringency measure index) in order to

23 evaluate the dynamics leading to the second wave. We used (pre)admission screening results

24 from the major Antwerp hospitals for estimating community prevalences and incidences.

2543.545 samples were included (April - November 2020). High SARS-CoV-2 carriership rates

26 (mean week prevalence of 1.3\%) were found in the general Antwerp population. 35.4\% of

27 positive cases carried high viral loads. Only a small proportion (15.3\%) of the viral circulation

28 was detected by the nationally implemented testing policy. In the weeks before the second

29 Belgian wave, increasing prevalences and incidences were found, together with country-wide

30 easing of restriction measures. In our opinion these findings have led to origin of the second

31 viral wave.

32 Keywords: SARS-CoV-2; Belgium; second wave; driver; contact-tracing; prevalence;

33 incidence

34 Conflict of interest: None

35 Funding statement: No funding 
medRxiv preprint doi: https://doi.org/10.1101/2020.12.09.20246462; this version posted December 24,2020 . The copyright holder for this preprint (which was not certified by peer review) is the author/funder, who has granted medRxiv a license to display the preprint in perpetuity.

It is made available under a CC-BY-NC-ND 4.0 International license .

\section{INTRODUCTION}

37 Since March 2020, the world has been in the grips of a pandemic caused by the Severe Acute

38 Respiratory Syndrome virus type 2 (SARS-CoV-2) leading to excess mortality and morbidity.

39 The virus has a detrimental impact on both economic and psycho-social well-being ${ }^{1}$.

40 Belgium was highly impacted, having had to deal with two waves up to November 2020: the

41 first from the beginning of March to the end of May, the second during the fall (showing a

42 decline in November). The first wave was contained by implementing a full lockdown starting

on 14 March 2020. The first measures to ease restrictions were introduced on 4 June 2020.

44 Despite warnings from various Belgian key expert virologists and epidemiologists in

45 September 2020, the government decided to ease restrictions further, having been encouraged

46 by various pressure groups and public opinion. Belgium faced its second wave as from

47 October 2020 (Figure 1).

Until now, little is known about the dynamics and prevalence of asymptomatic carriership and viral loads in the general Belgian population ${ }^{2}$. Furthermore, the role of the different age categories in the viral spread has not been fully elucidated ${ }^{3}$.

51 Since the major Antwerp hospitals implemented extensive (pre-)admission screening of

52 asymptomatic cases in April 2020 (eg. prior to elective surgery or endoscopic procedures),

53 and have continued to do so, they possess valuable information regarding the actual

54 prevalence of the virus in the general population throughout the pandemic period.

55 The goal of this study was to determine rates of carriership and viral loads in the general 
58

\section{METHODS}

\section{DATA COLLECTION}

During the period 27 April to 15 November 2020, we collected SARS-CoV-2 positivity data from (pre)admission screenings from the following hospitals: the Antwerp University Hospital (UZA), the multiple site public hospital ZiekenhuisNetwerk Antwerpen (ZNA), and the major multiple site private Antwerp hospital GemeenschapsZusters Antwerpen (GZA). Together they account for approximately $90 \%$ of hospital bed capacity (3697 hospital beds) in the city of Antwerp.

(Pre-)admission screenings were defined as follows: pre-hospital screenings prior to elective admissions (GZA, UZA, ZNA), and systematic admission screenings in asymptomatic patients admitted for other reasons than COVID-19 (GZA, UZA). Screenings of high/low risk contacts or individuals with symptoms were excluded.

A distinction in test indications was obtained by implementing different sample flows per indication (pre-admission screenings were performed by a nurse at patients' homes for the inclusions from UZA and ZNA, and screenings performed in a drive-through swab laboratory, or during a pre-visit at the swab laboratory, from UZA and GZA respectively). Unique test codes were also used by GZA and UZA for registering the swab samples in the Laboratory Information System (LIS).

Samples were analysed in the laboratory attached to the hospital of the prescribing physician. All laboratories are certified by the Belgian government (BELAC). The following molecular techniques and platforms were used:

In the clinical laboratory of GZA, nucleic acids were extracted on STARlet IVD® (Seegene INC., Seoul, Korea) using the Viral DNA/RNA C-kit. Subsequently SARS-CoV-2 qPCR (CDC N1 target) was performed on a Quantstudio 7 flex qPCR cycler® of Thermo Fisher 
medRxiv preprint doi: https://doi.org/10.1101/2020.12.09.20246462; this version posted December 24, 2020. The copyright holder for this preprint (which was not certified by peer review) is the author/funder, who has granted medRxiv a license to display the preprint in perpetuity.

It is made available under a CC-BY-NC-ND 4.0 International license .

82 Scientific (Waltham, MA, USA) according to the protocol published by the Centers of 83 Disease Control and Prevention (CDC).

84 The laboratory of UZA used the Xpert Xpress SARS-CoV-2 test detecting E and N2 target on the GeneXpert ${ }^{\circledR}$ Platform (Cepheid, USA) as per manufacturer’s instructions. Alternatively, an in-house PCR was performed detecting E target according to Corman et al. 2020 with extraction on NucliSens EasyMag® (Biomérieux, France) or QiaSymphony® (Qiagen, The Netherlands) and amplification with Cobas LightCycler 480 II® or Cobas z480 (Roche Molecular Diagnostics, Switzerland). Alternatively, a BD MAX SARS-CoV-2 kit was used detecting N1 and N2 target with an all-in one extraction amplification on the BD MAX® platform (Becton Dickinson, USA).

In the laboratory of ZNA, nucleic acids were extracted on MagNA Pure 96 using the MagNA Pure 96 DNA and Viral NA Small Volume Kit (Roche Molecular Diagnostics, Switzerland). Subsequently SARS-CoV-2 qPCR (N1 target) was performed on a LightCycler 480 qPCR cycler according to the protocol published by the CDC. Alternatively, nucleic acids were extracted on KingFisher Flex using the MagMAX Viral/Pathogen II Nucleic Acid Isolation Kit. These extracts were analysed on a Quantstudio 5 qPCR cycler using the TaqPath ${ }^{\mathrm{TM}}$ COVID-19 CE-IVD RT-PCR Kit (ThermoFisher Scientific). threshold $(\mathrm{Ct})$ value (or alternatively Crossing point $(\mathrm{Cp})$ ) if available (GZA, ZNA) were retrieved from the LIS for each patient, and transferred to a central ZNA-based and secured

102 database.

103 The following data were collected from the Belgian governmental scientific institution, Sciensano ${ }^{4}$ : absolute numbers (weekly) of positively detected cases for Antwerp province, 
admitted patients at the hospital for Antwerp province, and returning travelers in August 2020 with positivity rate (only available on national level).

The following data were collected from the Flemish Agency for Care and Health (governmental agency responsible for the contact-tracing policy) for Antwerp province by using the information from the web-based and secured database (Controle-toren) ${ }^{5}$ : percentages (weekly) of successfully (by phone) contacted positive cases in the Antwerp province. Age distributions for the Antwerp province were obtained from Statistiek Vlaanderen ${ }^{6}$.

We used the Oxford COVID-19 Government Response Stringency index to estimate governmental measures. The index goes from zero (no restrictions) to hundred (strictest) ${ }^{7}$.

\section{DATA ANALYSES AND DEFINITIONS}

Cases with domicile outside the Antwerp province were excluded for further analysis. SARSCoV-2 carriership was estimated by calculation of the weekly asymptomatic positivity rate in the study population. The incidence was calculated by using an estimated duration of PCR positiveness of seventeen days as was found by Cevik and colleagues ${ }^{8}$. The percentage of the cohort infected by SARS-CoV-2 (for the whole investigated period) was calculated by adding up all estimated week incidences. By dividing the absolute weekly numbers of positively tested cases in the province by the number of province inhabitants (1.858 million) in the province, the percentage of positively tested patients in the Antwerp province was calculated. The percentage of weekly new COVID-19 hospital admitted patients in the Antwerp province was calculated by dividing the absolute weekly number of admitted patients by the number of inhabitants in the province. 
medRxiv preprint doi: https://doi.org/10.1101/2020.12.09.20246462; this version posted December 24, 2020. The copyright holder for this preprint (which was not certified by peer review) is the author/funder, who has granted medRxiv a license to display the preprint in perpetuity.

It is made available under a CC-BY-NC-ND 4.0 International license .

128 Viral loads (only available for GZA and ZNA) were calculated by extrapolation of the $\mathrm{Ct} / \mathrm{Cp}$

129 values corresponding to 5000 genome equivalents per $\mathrm{mL}$ of the AccuPlex ${ }^{\mathrm{TM}} \mathrm{SARS}-\mathrm{CoV}-2$

130 full genome reference material (Seracare). A high viral load was defined as $>=256000$ viral

131 copies $/ \mathrm{mL}^{9}$. Ratios of positive cases (on a weekly basis; all inclusions) with high viral loads

132 were plotted on the same timeline as the plotted estimated incidences.

133

134 Mean positivity ratios per age decade (0-10 y, 11-20 y, 21-30 y, 31-40 y, 41-50 y, 51-60 y,

135 61-70 y, 71-80 y, 81-90 y, 90+ y) were investigated for the investigated cohort. Positivity

136 ratios of carriership were calculated for preschools (0-4 y), primary schools $(5-11 \mathrm{y})$ and

137 secondary schools (12-18 y). The mean positivity ratio was also assessed for (pre)school

138 children (0-18 y) and the elderly $(+80 \mathrm{y})$. Box-whisker plots represent the viral load among

139 different age categories.

140

141 Ethical approvals were obtained by the hospital Institutional Boards (GZA: Approval $\mathrm{N}^{\circ}$

142 200906RETRO; UZA: Approval N001355; ZNA: Approval N 5416). 


\section{RESULTS}

145 Overall, 43.545 cases were identified of which 38.763 cases $(89.0 \%)$ were included. The 146 results of 4782 cases $(11.0 \%)$ were excluded since domicile (based on postal code) was

147 outside Antwerp province. GZA, UZA, and ZNA accounted for respectively $53.2 \%, 34.6 \%$

148 and $10.7 \%$ of included cases. The overall SARS-CoV-2 positivity rate was $1.3 \%(\mathrm{n}=520)$.

149 Younger age groups ( $<21$ years old) were underrepresented in the investigated cohort as 150 compared to the Antwerp province $(9.0 \%$ versus $22.3 \% ; p<0.01)$. Age groups of $>70$ years

151 old were overrepresented in the cohort $(25.0 \%$ versus $14.1 \%, p<0.01)$. The distribution of 152 cases was not equally dispersed throughout Antwerp province with an underweight of cases 153 from the city of Antwerp versus the Antwerp province (20.8\% of cases had domicile in the 154 city of Antwerp, versus $26.8 \%$ of inhabitants for the whole Antwerp province $p<0.01)$. Cases 155 with domicile in the city of Antwerp $(n=8067)$ had an overall positivity rate of $1.8 \%$, whereas cases with domicile outside the city of Antwerp $(n=30696)$ had an overall positivity rate of $1.2 \%(p<0.01)$.

Estimated carriership (with high viral loads), estimated weekly new cases and number of admissions are shown in Figure 1. Calculated weekly cohort carriership varied between $0.1 \%$ (week of 29 June) and $8.6 \%$ (week of 26 October). The mean week percentage was $1.5 \%$. 18 May, 1 June, 22 June, 29 June, 6 July, 13 July and 24 August) and $6.7 \%$ (week of 26 October). The mean week ratio was $0.8 \%$. Overall, the percentage of positive carriers with high viral loads was $35.4 \%$. The calculated weekly incidence varied between $0.0 \%$ (see Figure 2) and $6.5 \%$ (week of 19 October). The mean week incidence was $0.7 \%$. Overall, we 
medRxiv preprint doi: https://doi.org/10.1101/2020.12.09.20246462; this version posted December 24,2020 . The copyright holder for this preprint (which was not certified by peer review) is the author/funder, who has granted medRxiv a license to display the preprint in perpetuity.

It is made available under a CC-BY-NC-ND 4.0 International license .

168 period from 27 April to 15 November. $3.1 \%$ of Antwerp province inhabitants tested positive 169 in the investigated period (Sciensano data). In August 2020, 1.4 million Belgians (12.2\% of

170 Belgian population) filled in a Passenger Locater Form. 2\% of travelers tested positive for

171 SARS-CoV-2. On population level, this equals a potential increase of $0.2 \%$ in SARS-CoV-2

172 carrier-rate.

173 The percentage of weekly new hospital admissions varied between $0.00 \%$ (see Figure 1) and $1740.02 \%$ (week of 26 October, 2 November, and 9 November) of the Antwerp province 175 population. The mean ratio of weekly detected cases versus the estimated weekly incidence 176 was $29.1 \%$ (range: $2.9 \%-100 \%$ ). The percentage of successfully contacted positive cases 177 varied between $54.0 \%$ (week of 22 June) and $94.0 \%$ (week of 26 October) for the Antwerp 178 province with a mean percentage of successfully contacted positive cases of $83.0 \%$ (data only 179 available from 1 June to 15 November since registration only started on 1 June).

180 The SARS-CoV-2 positivity rate according to age is $0.9 \%$ (95\% Confidence Interval (CI): $0.4-1.5 \%)(\mathrm{n}=1292)$ for daycare children $(0-4$ years $), 1.0 \%(95 \%$ CI: $0.5-1.9 \%)(\mathrm{n}=877)$

182 for primary school children (5-12 years), $0.8 \%(95 \%$ CI: $0.3-1.6 \%)(\mathrm{n}=878)$ for secondary 183 school children (13-18 years), $0.9 \%$ (95\% CI: $0.6-1.3 \%)(n=3047)$ for overall school-aged 184 civilians $(0-18$ years $), 1.4 \%(95 \%$ CI: $1.3-1.5 \%)(\mathrm{n}=35637)$ for adults $(>18$ years $)$ and $1852.6 \%(95 \%$ CI: $2.1-3.2 \%)(\mathrm{n}=4033)$ for the elderly $(>80$ years $)$. The distribution of viral 186 loads and ratios of carriers with high viral loads among different age categories are presented 187 in Figure 2 and 3 respectively.

188 The results of the Oxford Stringency Index are shown in Figure 1. 


\section{DISCUSSION}

190

191

192

Numerous reports provide data indicating that asymptomatic (or pre-symptomatic) subjects can transmit COVID-19 with high efficiency ${ }^{10,11}$. In the living review paper of Buitrago-

Garcia, the secondary attack rate is only slightly lower in contacts of people with asymptomatic infection than in those with symptomatic infection (relative risk $0.35,95 \% \mathrm{CI}$ $0.10-1.27)^{12}$. Mathematical modelling studies (not peer reviewed) have suggested that asymptomatic individuals might be major drivers for the growth of the COVID-19 pandemic $^{13}$.

We found high positivity ratios of asymptomatic carriership in our investigated cohort of Antwerp inhabitants throughout the investigated pandemic period (27 April to 14 November 2020). Lowest positivity ratios were seen at the end of June (week of 29 June): after a period of a full lockdown and only minor easing of containment measures, SARS-CoV-2 positivity ratios were found to be at levels of 1 out of 1000 samples. Similar or even far lower prevalences led to massive screening programs in China in order to stop further viral spread ${ }^{14}$.

Taking into account the SARS-CoV-2 key transmission epidemiological parameters (estimated $\mathrm{R}_{0}$ factor of 2.0 and a dispersion factor of 0.10 ), a strategy accepting prevalences above $1 \%$ (the overall average in our cohort being $1.3 \%$ ) together with the simultaneously reopening of a locked community were, in our opinion, the perfect ingredients for rapid escalation towards a subsequent second national wave ${ }^{15}$. This finding is important as Belgium has chosen a strategy of accepting significant circulation of the virus within the population without having an accurate insight of past and actual viral prevalences (in contrast to eg. Luxemburg and China, where thorough search and/or isolation programs have been set up ${ }^{14,16}$. Also, pressure is already increasing to further ease the contingency measures taken in order to control the second wave. 
It is made available under a CC-BY-NC-ND 4.0 International license .

213 The finding that, due to the implemented testing and tracing strategy, only marginal numbers

214 of positive cases were detected (we estimated that, by extrapolation of cohort data, $20.3 \%$ of

215 the Antwerp population contracted the virus in the study period, but only $3.1 \%$ (15.3\% of

216 estimated positieve cases) were effectively tested positively) and subsequently traced (83,

217 range: $54 \%$ - $94 \%$ ), even in the periods of upward movement of the curves, was probably

218 another important contributing factor to the uncontrollable rapid further viral spread seen in

219 October 2020. The hypothesis of underestimated viral circulation in Belgium has also been

220 put forward by Herzog and colleagues, by analyzing epi-serological data ${ }^{17}$. Since we only

221 measured the base-line (population wide) prevalence, our estimation may even be an

222 underestimation of the real viral circulation, since outbreaks and clusters are not represented

223 in our analysis, but may have been picked up in documented testing numbers (Sciensano). On

224 the other hand, the underrepresentation of the younger age groups versus the

225 overrepresenation of the older age groups in the investigated cohort leads to an upward bias.

226 Furthermore, backward tracing has not been implemented optimally to date by the

227 governmental task force ${ }^{18}$. We argue that the Belgian testing and tracing strategy was not able

to contain and monitor the pandemic in Belgium adequately, this being one of the major

ingredients of a failing containment policy leading to the second national wave.

The province of Antwerp was one of the three Belgian provinces (out of 10) with highest number of tests per inhabitants ${ }^{4,5}$. There is no reason for postulating an exceptional role of Antwerp province in Belgium as being a highly affected province. Inversely, the southern part of the country was affected more severely in the second wave, as shown in the governmental Sciensano data.

Interestingly, we also found higher proportions of carriers in the city of Antwerp (1.8\%) than in the province of Antwerp $(1.2 \% ; p<0.01)$. This reflects a national trend: the second wave was more prevalent in crowded bigger capital cities ${ }^{4}$. 
It is made available under a CC-BY-NC-ND 4.0 International license .

238 With regard to positivity ratios according to age category, we found high numbers (around 1

$239 \%$ throughout the investigated period) in school children and young adults (0-30 years).

240 Positivity ratios of young adults (21-40 years-old) were significantly higher than the adult

241 population aged $51-70$ years $(p<0.01)$.

242 Although the role of children as main drivers of transmission is still debated, our finding may

243 be another argument for active transmission in these age groups $s^{20,21,22}$. A recent

244 seroprevalence survey in two Belgian municipalities (one highly affected, the other hardly

245 affected) also showed equivalent proportions of infections in primary school children versus

246 adolescents in the first three years of secondary education ${ }^{23}$.

247 On the other hand, if children were equally susceptible, one might expect even higher rates of

248 carriership, since children were less restricted in the number of contacts (summercamps,

249 schools were open from 1 September 2020). Since we were not able to correct for number of

250 contacts, we cannot further determine the value of this hypothesis.

251 With regard to age distribution, another interesting finding is the high overall percentage of

252 positivity ratios in the elderly $(+70 \mathrm{y})$. In our hypothesis, this is the reflection of the

253 augmented transmission risks in residential care homes.

254 We also found significant proportions of carriers with high viral loads (on average $35.4 \%$ of

255 all inclusions). In the week of 26 October, we estimate that $7.0 \%$ of Antwerp inhabitants were

256 carrying high viral loads. Evaluating the whole investigated period, on average $0.7 \%$ of the

257 population was carrying high viral loads. Although the link of viral load with contagiousness

258 has not been established, this might have been an important factor in the spread of the virus ${ }^{19}$.

259 Viral loads in younger age groups were not lower than viral loads in the working age

260 population. (Figure 2) In another non-peer-reviewed publication, it was also shown that there

261 is no significant difference between viral loads in 1-20 year-olds as compared to 21-100 year- 
medRxiv preprint doi: https://doi.org/10.1101/2020.12.09.20246462; this version posted December 24,2020 . The copyright holder for this preprint (which was not certified by peer review) is the author/funder, who has granted medRxiv a license to display the preprint in perpetuity.

It is made available under a CC-BY-NC-ND 4.0 International license .

262 old adults ${ }^{24}$. Furthermore, another study suggests that the viral load in children below 5 years

263 of age with mild to moderate COVID-19 symptoms is higher than in older children and

264 adults $^{25}$.

265 In our hypothesis, positive children may have further introduced the virus into households,

266 which suggests that this is a potentially underestimated factor in the derailing of the situation

267 in September 2020.

268 Interestingly, we found significantly higher proportions of carriers with high viral loads in the 269 elder age categories. The combination of higher prevalences and higher ratios of carriers with 270 high viral loads in this age group might be an important driver of the abundance of outbreaks

271 and associated excess morbidity and mortality seen in retirement homes.

272 Overall, not recognizing the presence and potential important role of the asymptomatic 273 carriers with higher viral loads may also have been another ingredient which led to the 274 subsequent second wave.

275 In our opinion, the role of the returning travelers was very limited. In August $12.2 \%$ of the 276 Belgian population filled in a Passenger Locater form. About 2\% of returning travelers tested 277 positive. On a population level, this may have led to an increase of $0.2 \%$ in carriership rates.

278 On the positive side, we found that by implementing strict contingency measures (i.e.

279 following the tightening and easing advice of experts) even substantial viral circulation of

280 around $1 \%$ can be controlled: the ratio of positive carriers was contained in the period

281 between 27 April and 14 September (19 weeks) without overstretching health care capacities.

282 However, the efforts required to maintain controllable containment were enormous, thereby

283 putting high pressure on social (limited number of contacts) and economic well-being (Oxford

284 Stringency Index not below 50.0 between 27 April and 14 September). 
It is made available under a CC-BY-NC-ND 4.0 International license .

285 Finally, we come to our last driver of the second wave, probably the most important one. Mid to end September, key Belgian epidemiologists, virologists and biostatisticians warned the temporary government of the possible rapid escalation in numbers of new infections and admissions, based on available data. The government decided not to follow their advice, and implemented a strategy that eased restriction measures (Oxford Stringency Index on 14 September: 52.8; 5 October: 47.2 ) in a time when there was a steadily increasing number of new infections (incidence increased from $0.9 \%$ the week of 14 September to $2.3 \%$ the week of 5 October). They were being encouraged to carry out this strategy by various pressure groups.

In October, Belgium was facing a second wave with a rapid increase in numbers of COVID admissions, thereby highly impacting the health care system and hospital facilities.

The limitations of this study include that (weak positive) asymptomatic cases could have corrresponded to previous infections with persistant existence of detectable RNA. This may have biased the results. However, the rapid decrease of positivity ratios after the implementation of extra measures (second pandemic wave) suggests we predominantly included active infections. Although the phenomenon of prolonged shedders does certainly exist, our data suggest that it is relatively insignificant and does not affect the major findings in this paper. Also, the median duration of positive results has been shown to be two to three weeks ${ }^{4}$. Another limitation is that we did not follow up positive/negative cases. We did not link the data to secondary COVID-19 cases, thus not establishing the contagiousness of positive cases. The screenings were linked to hospital procedures/admissions. Although we can accept these screenings as random samples from the community, the cohort is not a representative sample from the community: data points were not equally distributed in the

307 Antwerp province, and age distributions were not representative for the Antwerp province (underestimation of younger age groups, and overestimation of older age groups). 
medRxiv preprint doi: https://doi.org/10.1101/2020.12.09.20246462; this version posted December 24, 2020. The copyright holder for this preprint (which was not certified by peer review) is the author/funder, who has granted medRxiv a license to display the preprint in perpetuity.

It is made available under a CC-BY-NC-ND 4.0 International license .

309 In conclusion, we found that SARS-CoV-2 was significantly present in the Antwerp province

310 population in the period after the first wave. The virus circulated in all age groups with a

311 predomincance in the elderly. $1.3 \%$ of the investigated cohort tested positive for SARS-CoV-

3122 with $35 \%$ carrying high viral loads. The testing and contact-tracing policy only detected a

313 small proportion of the real viral circulation. The restriction measures were eased in a period

314 of increasing incidences. The combination of these factors were, in our opinion, the

315 ingredients for the onset of the second wave. If Belgium chooses to accept a certain viral

316 circulation, a very strict barometer has to be put into place, in order to prevent further

317 worsening of the pandemic situation. The positivity rates in (pre)admission screening results

318 may be an important tool;

320 Acknowledgements: None

322 Author Bio:

323 Dr. Reinout Naesens is Head of the Infection Prevention and Control Department and member

324 of the Medical Microbiology Department of the ZNA group, the largest public hospital in

325 Belgium. 
medRxiv preprint doi: https://doi.org/10.1101/2020.12.09.20246462; this version posted December 24, 2020. The copyright holder for this preprint (which was not certified by peer review) is the author/funder, who has granted medRxiv a license to display the preprint in perpetuity.

It is made available under a CC-BY-NC-ND 4.0 International license .

326

327

328

\section{REFERENCES}

1. World Health Organisation, World Health Organisation situation reports, https://www.who.int/emergencies/diseases/novel-coronavirus-2019/situation-reports. Accessed 2 december 2020.

2. Byambasuren O, Cardona M, Bell K, Clark J, McLaws M-L, Glasziou P. Estimating the extent of true asymptomatic COVID-19 and its potential for community transmission: systematic review and meta-analysis. medRxiv. 2020; (published online September 13.) (preprint) doi: https://doi.org/10.1101/2020.05.10.20097543

3. Castagnoli R, Votto M, Licari A, Brambilla I, Bruno R, Perlini S, et al. Severe Acute Respiratory Syndrome Coronavirus 2 (SARS-CoV-2) Infection in Children and Adolescents: A Systematic Review. JAMA Pediatr. 2020;174:882-889. doi:10.1001/jamapediatrics.2020.1467.

4. Sciensano, https://epistat.wiv-isp.be/covid/. Accessed 2 december 2020.

5. Toezicht Volksgezondheid, https://zorgatlas.vlaanderen.be. Accessed 2 december 2020.

6. Statistiek Vlaanderen, https://www.statistiekvlaanderen.be/nl/bevolking-naar-leeftijden-geslacht. Accessed 2 december 2020.

7. Oxford COVID-19 Government Response Tracker, https://covidtracker.bsg.ox.ac.uk/. Accessed 2 december 2020.

8. Cevik M, Tate M, Lloyd O, Maraolo AE. SARS-CoV-2, SARS-CoV, and MERS-CoV viral load dynamics, duration of viral shedding, and infectiousness: a sytematic review and meta-analysis. Lancet Microb. 2020. Online first. doi: https://doi.org/10.1016/S2666-5247(20)30172-5. 
medRxiv preprint doi: https://doi.org/10.1101/2020.12.09.20246462; this version posted December 24,2020 . The copyright holder for this preprint (which was not certified by peer review) is the author/funder, who has granted medRxiv a license to display the preprint in perpetuity.

It is made available under a CC-BY-NC-ND 4.0 International license.

9. Bullard J, Dust K, Funk D, Strong JE, Alexander D, Garnett L, et al. Predicting infectious SARS-CoV-2 from diagnostic samples. Clin Infect Dis. 2020;22:ciaa638. doi: 10.1093/cid/ciaa638.

10. Koh WC, Naing L, Chaw L, Rosledzana MA, Alikhan MF, Jamaludin SA, et al. What do we know about SARS-CoV-2 transmission? A systematic review and meta-analysis of the secondary attack rate and associated risk factors. PLoS One. 2020;15(10):e0240205. doi: 10.1371/journal.pone.0240205.

11. Mizumoto K, Kagaya K, Zarebski A, Chowell G. Estimating the asymptomatic proportion of coronavirus disease 2019 (COVID-19) cases on board the Diamond Princess cruise ship, Yokohama, Japan, 2020. Euro Surveill. 2020;25(10):2000180. doi: 10.2807/1560-7917.ES.2020.25.10.2000180.

12. Buitgrago-Garcia DC, Egli-Gany D, Counotte MJ, Hossmnn S., Imeri H, Ipekci AM, et al. Asymptomatic SARS-CoV-2 infections: a living systematic review and meta-analysis. medRxiv. 2020; (published online July 28.) (preprint) doi: https://doi.org/10.1101/2020.04.25.20079103.

13. Dobrovolny HM. Modeling the role of asymptomatics in infection spread with application to SARS-CoV-2. PLoS One 2020; 15:e0236976. doi: 10.1371/journal.pone.0236976.

14. Health Commission of Hubei Province. Daily report on epidemic situation of COVID19 in Hubei province. http://wjw.hubei.gov.cn/bmdt/ztzl/fkxxgzbdgrfyyq/xxfb/index.shtml. Accessed 2 december 2020.

15. Kucharski AJ, Russell TW, Diamond C, Liu Y, Edmunds J, Funk S, Eggo RM; Centre for Mathematical Modelling of Infectious Diseases COVID-19 working group. Early 
dynamics of transmission and control of COVID-19: a mathematical modelling study. Lancet Infect Dis. 2020; pii:S1473-3099(20)30144-4.

16. https://covid19.public.lu/en/testing.html Accessed 2 december 2020. of IgG antibodies against SARS coronavirus 2 in Belgium - a serial prospective crosssectional nationwide study of residual samples. medRxiv. 2020; (published online October 1.) (preprint) doi: https://doi.org/10.1101/2020.06.08.20125179.

18. Endo A; Leclerc QJ, Knight GM, Medley GF, Atkins KE, Funk S, et al. Implication of backward contact tracing in the presence of overdispersed transmission in COVID-19 outbreaks. Wellcome Open Res. 2020;5:239. doi: 10.12688/wellcomeopenres.16344.1.

19. Zou L, Ruan F, Huang M, Liang L, Huang H, Hong Z, et al. SARSCoV-2 Viral Load in Upper Respiratory Specimens of Infected Patients. N Engl J Med. 2020;382:11771179. doi: https://www.nejm.org/doi/full/10.1056/NEJMc2001737.

20. Jones TC, Mühlemann B, Veith T, Biele G, Zuchowski M, Hoffmann J, et al. An analysis of SARS-CoV-2 viral load by patient age. medRxiv. 2020; (preprint) doi: https://doi.org/10.1101/2020.06.08.20125484.

21. Viner RM, Russell SJ, Croker H, Packer J, Ward J, Stansfield C, et al. School closure and management practices during coronavirus outbreaks including COVID-19: a rapid systematic review. Lancet Child \& Adolescent Health. 2020;4(5):397-404. doi: 10.1016/S2352-4642(20)30095-X.

22. Heavey L, Casey G, Kelly C, Kelly D, McDarby G. No evidence of secondary transmission of COVID-19 from children attending school in Ireland, 2020. Euro Surveillance: bulletin Europeen sur les maladies transmissibles = European communicable disease bulletin. 2020;25(21). doi: 10.2807/15607917.ES.2020.25.21.2000903. 
medRxiv preprint doi: https://doi.org/10.1101/2020.12.09.20246462; this version posted December 24, 2020. The copyright holder for this preprint (which was not certified by peer review) is the author/funder, who has granted medRxiv a license to display the preprint in perpetuity. It is made available under a CC-BY-NC-ND 4.0 International license .

398

399

400

401

402

403

404

405

406

407

408

409

23. Sciensano, https://www.sciensano.be/sites/default/files/limburg-validation-sarscov2_report_20201112_final.pdf. Accessed 2 December 2020.

24. Jones TC, Mühlemann B, Veith T, Zuchowski M, Hofmann J, Stein A, et al. An analysis of SARS-CoV-2 viral load by patient age. Available from: https://zoonosen.charite.de/fileadmin/user_upload/microsites/m_cc05/virologieccm/dateien_upload/Weitere_Dateien/analysis-of-SARS-CoV-2-viral-load-by-patientage.pdf. Accessed 2 December 2020.

25. Heald-Sargent T, Muller WJ, Zheng X, Rippe J, Patel AB, Kociolek LK. Age-Related Differences in Nasopharyngeal Severe Acute Respiratory Syndrome Coronavirus 2 (SARS-CoV-2) Levels in Patients With Mild to Moderate Coronavirus Disease 2019 (COVID-19). JAMA Pediatr. 2020;174(9):902-903.

doi: 10.1001/jamapediatrics.2020.3651. 
medRxiv preprint doi: https://doi.org/10.1101/2020.12.09.20246462; this version posted December 24, 2020. The copyright holder for this preprint (which was not certified by peer review) is the author/funder, who has granted medRxiv a license to display the preprint in perpetuity.

It is made available under a CC-BY-NC-ND 4.0 International license .

410 Table 1 Age distribution of included cases and age distribution of the province of Antwerp.

\begin{tabular}{lllll} 
Age & Number & Percentage of & Percentage of & $p$-value (difference in \\
category & of & inclusions & inhabitants in the & rates of inclusions \\
& inclusions & & Antwerp province & versus the Antwerp \\
& & & & province) \\
\hline $\mathbf{0 - 1 0} \mathbf{y}$ & 1971 & 5.1 & 11.3 & $p<0.01$ \\
$\mathbf{1 1 - 2 0} \mathbf{y}$ & 1493 & 3.9 & 11.0 & $p<0.01$ \\
$\mathbf{2 1 - 3 0} \mathbf{y}$ & 3942 & 10.2 & 12.1 & $p<0.01$ \\
$\mathbf{3 1 - 4 0} \mathbf{y}$ & 5110 & 13.2 & 13.1 & $p=0.83$ \\
$\mathbf{4 1 - 5 0} \mathbf{y}$ & 4376 & 11.3 & 12.7 & $p<0.01$ \\
$\mathbf{5 1 - 6 0} \mathbf{y}$ & 5993 & 15.5 & 14.0 & $p<0.01$ \\
$\mathbf{6 1 - 7 0} \mathbf{y}$ & 6194 & 16.0 & 11.8 & $p<0.01$ \\
$\mathbf{7 1 - 8 0} \mathbf{y}$ & 5651 & 14.6 & 8.2 & $p<0.01$ \\
$\mathbf{8 1 - 9 0} \mathbf{y}$ & 3450 & 8.9 & 4.9 & $p<0.01$ \\
$\mathbf{+ 9 0 ~ \mathbf { ~ }}$ & 583 & 1.5 & 1.0 & $p=0.23$ \\
\hline
\end{tabular}


medRxiv preprint doi: https://doi.org/10.1101/2020.12.09.20246462; this version posted December 24, 2020. The copyright holder for this preprint (which was not certified by peer review) is the author/funder, who has granted medRxiv a license to display the preprint in perpetuity. It is made available under a CC-BY-NC-ND 4.0 International license .

412 Table 2. Overall positivity rate of SARS-CoV-2 in asymptomatic carriers according to age 413 groups.

Age category Overall percentage of positive tests $95 \% \mathrm{CI}$

\begin{tabular}{|c|c|c|}
\hline $0-10 y$ & 1.0 & 0.6 to 1.5 \\
\hline $11-20 y$ & 1.3 & 0.8 to 2.0 \\
\hline $21-30 y$ & 1.6 & 1.3 to 2.1 \\
\hline $31-40 y$ & 1.6 & 1.3 to 2.0 \\
\hline $41-50 y$ & 1.2 & 0.9 to 1.6 \\
\hline $51-60 y$ & 1.0 & 0.7 to 1.2 \\
\hline $61-70 y$ & 0.9 & 0.7 to 1.1 \\
\hline $71-80 y$ & 1.2 & 0.9 to 1.5 \\
\hline $81-90 y$ & 2.7 & 2.2 to 3.3 \\
\hline$>90 y$ & 2.6 & 1.4 to 4.2 \\
\hline
\end{tabular}


medRxiv preprint doi: https://doi.org/10.1101/2020.12.09.20246462; this version posted December 24, 2020. The copyright holder for this preprint (which was not certified by peer review) is the author/funder, who has granted medRxiv a license to display the preprint in perpetuity. It is made available under a CC-BY-NC-ND 4.0 International license .

416 Figure 1. Estimated prevalence and incidence of SARS-CoV-2 carriers, estimated prevalence

417 of carriers with high viral loads, percentages of cases with confirmed a positive SARS-CoV-2

418 test and percentages of confirmed hospital admitted COVID cases in the Antwerp province. 
medRxiv preprint doi: https://doi.org/10.1101/2020.12.09.20246462; this version posted December 24, 2020. The copyright holder for this preprint (which was not certified by peer review) is the author/funder, who has granted medRxiv a license to display the preprint in perpetuity.

It is made available under a CC-BY-NC-ND 4.0 International license .

419 Figure 2. Viral loads according to age groups in asymptomatic carriers (viral loads only

420 available for GZA and ZNA). 
medRxiv preprint doi: https://doi.org/10.1101/2020.12.09.20246462; this version posted December 24, 2020. The copyright holder for this preprint (which was not certified by peer review) is the author/funder, who has granted medRxiv a license to display the preprint in perpetuity.

It is made available under a CC-BY-NC-ND 4.0 International license .

421 Figure 3. Proportion of asymptomatic carriers with high viral loads according to age category. 
\&

medRxiv preprint doi: https://doi.org/10.1101/2020.12.09.20246462; this version posted December 24, 2020. The copyright holder for this preprint (which was not certified by peer review) is the author/funder, who has granted medRxiv a license to display the preprint in perpetuity.

Ifis made available under a CC-BY-NC-ND 4.0 Internationallicense .

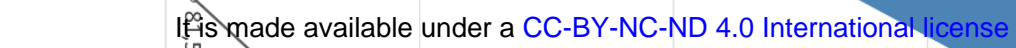




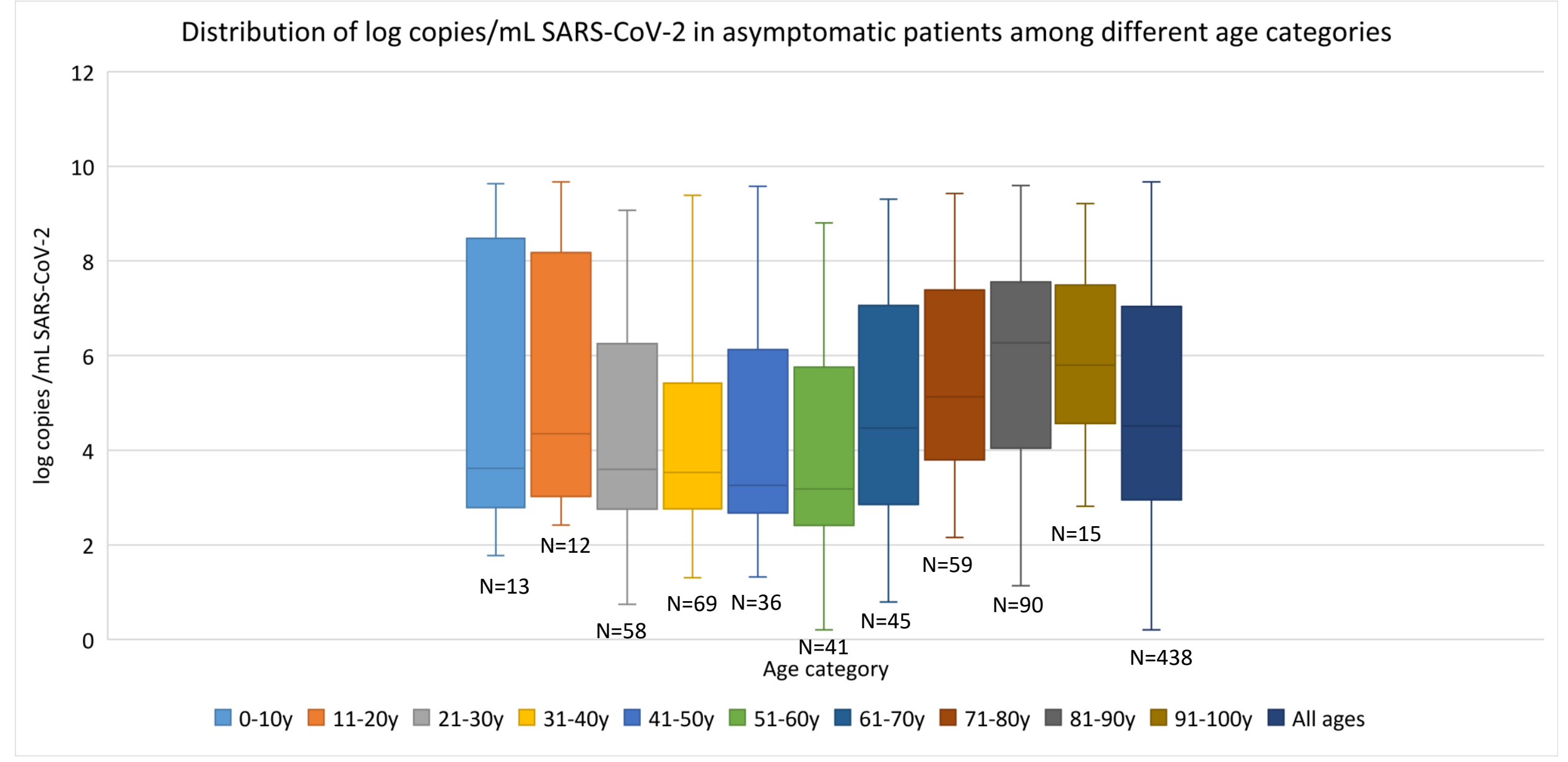


medRxiv preprint doi: https://doi.org/10.1101/2020.12.09.20246462; this version posted December 24, 2020. The copyright holder for this preprint (which was not certified by peer review) is the author/funder, who has granted medRxiv a license to display the preprint in perpetuity.

It is made available under a CC-BY-NC-ND 4.0 International license .

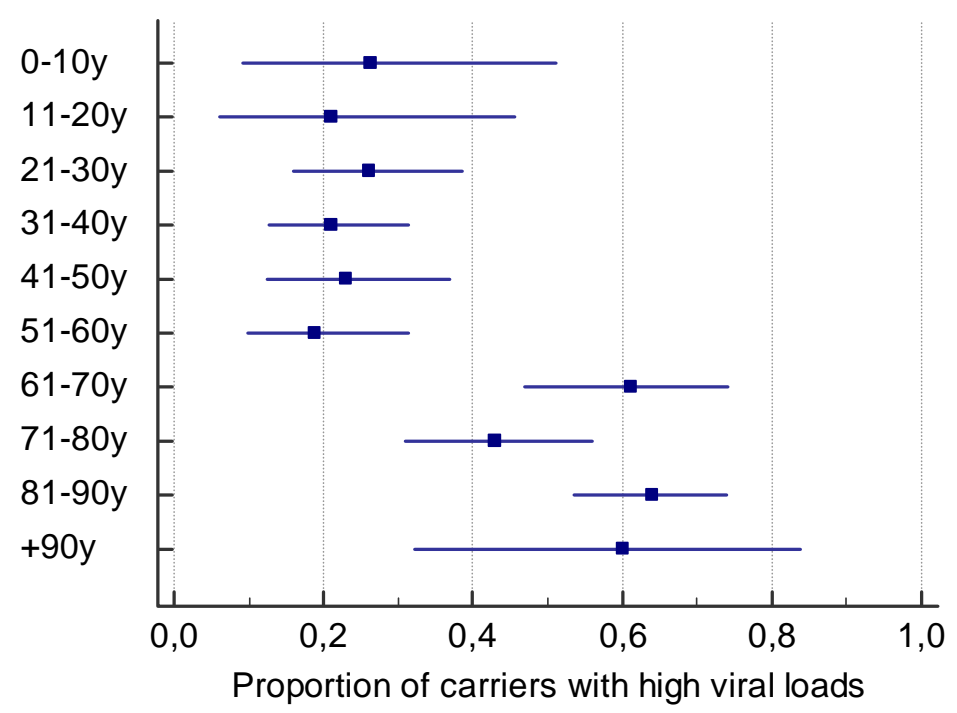

\begin{tabular}{|c|c|c|}
\hline Age category & $\begin{array}{c}\text { Proportion of carriers } \\
\text { with high viral loads } \mathbf{( \% )}\end{array}$ & $\mathbf{9 5} \mathbf{~} \mathbf{~ C l}$ \\
\hline $\mathbf{0 - 1 0 y}$ & 26.3 & $9.1-51.2$ \\
\hline $\mathbf{1 1 - 2 0 y}$ & 21.1 & $6.1-45.6$ \\
\hline $\mathbf{2 1 - 3 0 y}$ & 26.2 & $16.0-38.5$ \\
\hline $\mathbf{3 1 - 4 0 y}$ & 21.0 & $12.7-31.5$ \\
\hline $\mathbf{4 1 - 5 0 y}$ & 23.1 & $12.5-36.8$ \\
\hline $\mathbf{5 1 - 6 0 y}$ & 19.0 & $9.9-31.4$ \\
\hline $\mathbf{6 1 - 7 0 y}$ & 61.1 & $46.9-74.1$ \\
\hline $\mathbf{7 1 - 8 0 y}$ & 43.1 & $30.8-56.0$ \\
\hline $\mathbf{8 1 - 9 0 y}$ & 64.1 & $53.5-73.9$ \\
\hline $\mathbf{+ 9 0 y}$ & 60.0 & $32.2-83.7$ \\
\hline
\end{tabular}

